\title{
Life Skills Education for People with Disabilities at Blind Orphanage "Tuah Sakato" West Sumatra Indonesia
}

\author{
Jendriadi, Warlan Sukandar, Rona Rossa \\ STKIP Adzkia Padang, Indonesia \\ Email : rumbenasli@yahoo.co.id
}

\begin{abstract}
This research was done because there is still the wrong assumption in the society that it will be ashamed if one of the family members has suffered from a disability. Even, they do not ready to receive him. One of the disabilities cases is blind. It is indicated by not being able to see either totally or partially. The blind people are caused by the different background. Some suffer are congenital birth, this blindness occurred since they were born. Then, The others happened when they are still teenagers and even adults, which is caused by several factors such as illness, accident, style of reading, or blindness is an undetectable cause. This research tries to reveal the various life skills education provided by the administrators of Blind Orphanage Tuah Sakato in West Sumatera so that the cynical and apathetic impression on the blind disabled patients will be reduced or even lost by knowing the various life skills that they get during their education. Thus, there is no longer the assumption that people with blind disabilities are only used as a sacrifice for begging on the streets or just working as a masseur only. In addition, this research also tries to describe the impression of alumni after taking education at Blind Orphanage Tuah Sakato West Sumatra Indonesia. The method used in this research is qualitative descriptive with direct participation approach. The techniques used are observation, interview and participate in their daily activities. The results of this field research obtained a lot of information about life skills provided by the managers for their students. By providing many life skills, their students are ready to return to the community. There are many life skills that are providing there. They are; preparatory classes, massaging skills by recognizing the structure of the human body, the ability of foreign languages, the ability to cook, the ability to play music, memorize the Qoran and recitation of the Qoran with rhythm, the ability to make speeches and they also got the counseling guidance so that they can be optimistic to look for their future. From the interviews that the authors conducted to the alumni of Blind Orphanage Tuah Sakato who had completed his education there, the results obtained that 90 percent said they are very satisfied with life skills education that has been given by the managers of Blind Orphanage Tuah Sakato and they feel like getting a new family and they are also assisted to find work.
\end{abstract}

Keywords: life skills education, disability, blind

\section{INTRODUCTION}

Education is a process of self-realization in which an individual realizes and develops all of his potential. Education can take place at any time and in any place. Everyone, both children and adults, experience the process of education through what is encountered or what is done. According Hamalik (2005) that the function of education is essentially, is to prepare learners "Prepare" means that learners are essentially not ready, but need to be prepared and is preparing itself. This refers to the process that takes place before the learners are ready to plunge into real life.

Education when associated with the discussion of Life Skills (life skills) focused on schools and schooling systems, departing from the universalization that continues to expand and increase. Life skills, especially day-to-day life skills, are increasingly perceived as important for personal and collective lives that often face the phenomena of life with issues at the private, local, national, regional and global levels
Almost everyone is educated and conducts education. Because education is never separated from human life. Children receive education from their parents and when the children are moving towards adulthood, they are also tasked to educate their children (Pidarta, 2013)

One of the hallmarks of community life is a continuous and sustainable change known as modernization. People's lives enter a new phase, globalization. The advancement of information technology has eliminated geographical and cultural barriers.

Since there is no more partition in the nature of nan has seemed to shrink this, in fact there is no partition between us in particular in terms of achieving education. Education does not recognize boundaries of race, religion and even physical.

Nevertheless, the discrimination felt by people with disabilities still continues today even though the quantity has begun to decrease. Anni for example, Since childhood she suffered from polio. Conditions 
that force her to use a wheelchair wherever go. School times are the heaviest period her feels as a child. She told of how hurt she was when she saw other children taking gym or dancing lessons, while she could only sit in front of the class.

Fortunately, her parents in Kebumen, Central Java trained her for a strong mentality. Despite facing many obstacles to education in public schools, in fact Anni can get through all that. Even up to the college bench at Sebelas Maret University, Solo, Central Java.

Whereas according to Anni, inclusive schools have many roles for people with disabilities. Not only to gain knowledge, learning in public schools gives them the opportunity to foster self-confidence.

Now she is the Chairman of the Indonesian Association of Persons with Disabilities in East Kalimantan. She is also active in Aisyiah women's organizations, and encourages local governments to open inclusive schools for people with disabilities in the province. Unfortunately according to her, many schools only put inclusive predicate without applying the correct system. But so far, there has been no positive response from the education environment. "If we want to lead to an inclusive society, I think it is more appropriate that the education system being implemented is inclusive education. So not with special schools for people with disabilities only. This system has advantages, such as people with disabilities will feel confident, not distinguished from others, and get nothing like the other kids get. This system is also more competition for people with disabilities, competing with other students despite their limitations, "she continued.

A similar experience is experienced by Akhmad Soleh. He is a blind doctor who graduated from the State Islamic University, Sunan Kalijaga, Yogyakarta. Various refusals are always given by the school manager he wants to attend, from elementary, junior high, to university. Not infrequently, parents and themselves have to argue with school leaders in Kudus or Pemalang, Central Java, where he spent his childhood and adolescence.

Many schools refuse to accept Akhmad Soleh by reason of not having teachers who can teach the blind. He sometimes even had to ask the school manager to assume he was not in the class, and carry out the teaching and learning process as usual. Soleh did not ask to be privileged and considered to have special needs.

What he remembers most is when a private university where he has received his undergraduate education refuses to accept it, even though he has sent a notification letter received as a student. Soleh had taken the entrance exam at the university and was graduated. The university then sent a summons to send Soleh to college. On the first day of Soleh's arrival to the university, there was a rejection because it was only known that Soleh was a blind

"Obviously there was a summons for me, but the campus did not know I was a person with a disability. When I arrived, they were shocked, and then I was rejected for a variety of reasons, like no lecturer for people with disabilities. Just keep saying, let's just say I'm not there. Let me adjust that later. Whether I will succeed or not, that will be my business. Consider all the same and treat all students in the same way, "said Akhmad Soleh. Soleh also considered that many schools are labeled inclusive but have not fully understood the concept and ideology. Settling needs to be done, and the main thing is to improve the school manager's mindset. Persons with disabilities need not be privileged, they should be treated equally. If the education sector is more friendly, they can prove that limitations are not an obstacle. Anni Juwairiyah is a women's organization activist and has been a member of East Kalimantan Legislative Council.

While Akhmad Soleh was able to hold a doctorate, worked as a civil servant in Bantul Regency, Yogyakarta, and taught at several universities.

As academics, of course we have a very strategic role so there is no more gap between disabled and nondisability. If one may wish, no one is willing to seek trials with either partial or total loss of sight. But the wheels of life must run, they have hope to welcome a much brighter future ahead of the limitations they have.

They do not need to be pitied, they do not need to be spoiled, they just need a belief from us that they also have the abilities that normal people has. Like an angler language, they do not need fish, but they just need a bait so they can survive in a long time. The fishing line they expect is called skill or life skills to make them grow and grow.

The era that we are currently passing is already must demanding people to be a winner by risking competence. The main source of competence is good human resources (Anwar, 2004)

In the root words, according to Sumarni (2002) skills is another meaning of the skill. But this concept seems too narrow from the true meaning. so the term skills can be interpreted with other contexts of skill.

The function of learning life skills education is to help guide, train, encourage, shape and develop the learning function that is done by and become the responsibility of the teacher, that is the teacher or the trainer so that the student can make changes to him according to the purpose (Alquranulkarim Digital, 2017)

Therefore, with life skills education will be able to provide supplies to anyone without knowing any status. Because in the eyes of God all we have the same rights. What distinguishes others is the level of piety. As contained in the Qur'an letter of al-Hujurat verse 13 


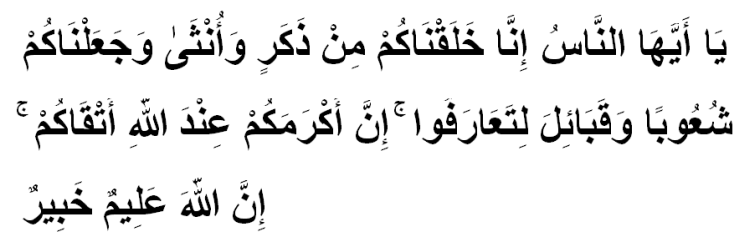

"O mankind, We created you from a man and a woman and made you nation and tribe so that you may know one another. Verily the most honorable among you by Allah is the most pious among you. Allah is the Knower, the Knower.

\section{METHOD}

This research is a research that will examine the problems that are social and dynamic. Therefore, the research method that researchers use is qualitative research to determine how to find, collect, process and analyze data research results. This qualitative research can be used to understand social interaction, for example by in-depth interviews so that clear patterns will be found.

In this study the researcher chose the type of qualitative research then the data obtained must be deep, clear and specific. Further explained by Sugiyono (2009) that the collection of data can be obtained from the results of observation, interview, documentation, and combined / triangulation. In this study researchers used data collection techniques with observation, documentation, and interviews.

\section{RESULTS AND DISCUSSION}

\section{Profile of Bina Netra Social Institution of West Sumatera}

PSBN Tuah Sakato was built on July 221993 through the assistance of OECF Japan LOAN of fiscal year 1992/1993 and 1997/1998. Panti started to operate on December 2, 1994 with the initial number of clients 20 people for the working area of West Sumatra province. As of April 1, 1995 the number of clients plus to 30 people and then on April 1, 1996 increased again to 50 people until now.

On April 1, 1998, Eselonering came down as an orphanage in social department with type B through Minister of Social Affairs Decree No 25 / HUK / 1998 dated April 15, 1999. Then in December 1998 a structural official was assigned and changed the name of the institution from PSBN Kalumbuk Padang to PSBN Tuah Sakato Padang. With the enactment of law No.22 of 1999 on OTODA and continued with the governor's decision number 22 of 201 on continued organization and administration of the technical implementation of the service, the PSBN Tuah Sakato become UPTD in the social offices of West Sumatra.

Bina Netra social house is located at Wisma
Bunda, Kalumbuk, Kuranji Subdistrict, Padang City of West Sumatra. This orphanage has the content of being a leading and reputable social service and rehabilitation institution in Sumatra to produce ethical and ethical disabilities people with the skills to live independently. While the mission of this social home is to improve the professionalism of structural, functional, technical and managerial officials in quantity and quality, increase cooperation with various levels of work, optimize the potential and social resources, improve facilities and infrastructure disabilities services, and empower the potential and service recipient capabilities.

Based on the PSBN booklet state that PSBN of West Sumatra Provinces (2017) that people with disabilities are people who can not see because the eye is damaged or can not count the fingers at a distance of 1 meter in front of it by using the sense of sight. Bina Netra is a social home that provides social rehabilitation to people with disabilities.

As for the purpose of providing services to clients is to restore a sense of self-esteem, self-confidence, love of work, awareness for achievement and responsibility to family and society. Furthermore, to improve the physical and skill abilities in social life, increasing the participation of families and communities in the business, the welfare of disabled people inadequate massage skills. according to (Hadi, 2005) that blind is another term of visual impairment.

\section{Life Skills Education for Disabled People at Bina Netra Social Institution of West Sumatera}

Mukti (2004) state that the purpose of life the skills development orientation is to provide a meaningful learning experience for learners that matches what is needed in everyday life. indeed, disabled persons including the blind have the same right and opportunity to receive education, whether it be Islamic religious education or awards.

Based on the results of observations and interviews of the authors with some speakers at social institutions Bina Netra West Sumatra, administrators trying to provide excellent service to the clients with full affection and patience. Beyond what the authors estimate, there are many life skills given to clients. initially, the authors suspect that the life skills received by clients who are studying at social institutions bina netra is the ability of massage alone. Apparently everything is not right. Due to many other skills they get among them.

\section{Physical and Mental Guidance}

Almost all clients are not ready with the conditions they are experiencing. The only thing ready is a person who from birth has a vision defect. With their closed 
vision they did not mean they were safe. They are still struggling to get treatment at the community sense health center. Because, if not treated their eyes will become enlarged and will have a bad effect on their eyesight.

In the activities of physical and mental guidance, there are some activities that they get among them sports guidance, orientation and mobility guidance, health guidance, character guidance, guidance of Islamic studies and maintenance of personal and family health. When Ramadhan is coming, the clients must attend Pesantren Ramadhan so that they understand with Islamic value and also they be a mubaligh to inform about of Islamic religion to the society. One of their activities we can see in the figure below.

\section{Social Guidance}

There are some services that clients obtain by clients related to social guidance among others; guidance of daily life, guidance of relations and social integrase, recreation and meeting of children and parents of clients.

\section{Business / work skills guidance}

Some of the guidance obtained by clients include massage and Sihatsu, fingerprinting skills, traditional musical instrument skills, voice vocal guidance, handy craft skills, Braille Arabic courses and computer program braile.

\section{Entrepreneurship guidance}

One of the most central concepts of life skill education programs is that education is expected to solve problems that arise because education must be able to synergize lessons into a life skill or skill in the hope that graduates will be able to solve problems which he is and will face. One of them is to create a job.

Although not able to see, the students in panti Bina Netra still taught skills that support them to be independent. one of which is by training the flower arranging using the sense of touch they have. they participate in the training of activities and skills training with passion and enthusiasm. for more details we can see on the figure below.

\section{CONCLUSIONS}

From the results of observations and interviews of authors with resource persons in the social organs blind Kalumbuk obtained conclusion that basic education is a process realized by individuals who should not discriminate the physical background of a person. All are entitled to be treated fairly and humanely.

There are several life skills acquired by clients in the social estates of neighboring West Sumatra, including: physical and mental guidance, social guidance, business / work skills guidance and entrepreneurial guidance.

\section{REFERENCES}

Alquranulkarim Digital. (2017). Quoted from https:// tafsirq.com/49-al-hujurat/ayat-13.

Anwar. (2004). Life Skills Education, Concepts and Applications. Bandung : Alfabeta.

Hadi, P. (2005). Independence of the Blind. Jakarta : Kemendiknas.

Hamalik, O. (2005). Curriculum and Learning. Jakarta: Bumi Aksara.

Mukti, A. (2004). Buletin LPM of Education, Quantum Transformation of Idealisme. Malang: UIN Maulana Malik Ibrahim Tarbiyah Faculty.

Pidarta, M. (2013). The Foundation of Education. Jakarta : Rineka Cipta.

Sumarni, S. (2002). Journal of Islamic Education Science. Yogyakarta : UIN Sunan Kalijaga.

Sugiyono. (2009). Quantitative Research Methods, Qualitative and $R \& D$. Bandung: Alfabeta. 